\title{
A study of $/ 1 /$ velarization in American English based on the Buckeye Corpus
}

\author{
Jae-Jin $\mathrm{Sa}^{*}$ \\ VERUM College, Catholic Kwandong University, Gangneung, Korea
}

\begin{abstract}
It has been widely recognized that there are two varieties of lateral liquid /1/, which are light /1/ (a non-velarized allophone) and dark /1/ (a velarized allophone). However, this categorical view has been challenged in recent studies, both on articulatory and acoustic aspects. The purpose of this study is to investigate whether to consider /1/ velarization as a continuum in American English and provide supporting data. A spontaneous American English speech database called the Buckeye Speech Corpus was used for the material. The formant frequencies of $/ 1 /$ in each syllable position were measured and analyzed statistically. The formant frequencies of $/ 1 /$ in each syllable position, especially F2 values, were significantly different from each other. The results showed that there were other significantly different varieties of /1/ in American English, which support the continuum view on /1/ velarization. Regarding the effect of the adjacent vowel, the backness of the adjacent vowels was shown to affect the degree of /1/ velarization, regardless of the syllable position of the lateral liquid. This result will help provide a solid ground for the continuum view.
\end{abstract}

Keywords: Buckeye corpus, lateral liquids, formant frequency, vowel context, velarization

\section{1. 서론}

영어의 설측음 $/ 1 /$ 에는 음절 말 환경에서 연구개음화된 변이 음인 어두운 / $/$ 과 그 밖의 환경인 음절 초 혹은 모음 사이에서 연구개음화되지 않고 나타나는 밝은 $/ 1 /$, 두 개의 변이음이 존재 한다는 점은 널리 알려져 있다. 하지만 오랜 시간 동안 설측음 의 변이음을 밝은 $/ 1 /$ 과 어두운 $/ 1 /$ 이라는 두 종류로 구분했던 시 각에 대해 조음적 특성과 음향적 측면에서 서로 구별되는 변이 음의 종류를 좀 더 세분화할 수 있다는 주장이 제기되었다.
이전 연구를 통해 미국영어의 설측음에는 음절 환경에 따라 두 개의 변이음이 존재한다는 사실이 밝혀졌고, $/ 1 /$ 의 이러한 두 개의 변이형에 대해 모음 앞 혹은 모음 사이의 $/ 1 /$ 은 밝은 $/ 1 /$ 로, 모음 뒤 환경의 /1/은 어두운 /1/로 설명하였다(Chomsky \& Halle, 1968; Jones, 1966; Ladefoged \& Johnson, 2014). 영어의 설측음에 대한 조음적 측면에서의 연구에서는 $/ 1 /$ 을 생성하는 과정에 있 어서 설첨이 올라가면서 설배가 뒤로 물러나는 동작이 동반된 다는 것을 보여주었다(Jones, 1966; Sproat \& Fujimura, 1993; Turton, 2014). Sproat \& Fujimura(1993)는 영어의 /1/을 생성하는

* ba2u@cku.ac.kr, Corresponding author

Received 31 May 2021; Revised 19 June 2021; Accepted 21 June 2021

(C) Copyright 2021 Korean Society of Speech Sciences. This is an Open-Access article distributed under the terms of the Creative Commons Attribution NonCommercial License (http://creativecommons.org/licenses/by-nc/4.0) which permits unrestricted non-commercial use, distribution, and reproduction in any medium, provided the original work is properly cited. 
데 설첨의 움직임과 설배의 움직임이 모두 필요하고, $/ 1 /$ 의 변이 음들의 차이는 설첨과 설배의 움직임이 실현되는 정도와 이들 움직임이 각각 일어나는 시기가 어떻게 다른지에 따라 결정된 다는 점을 알아냈다. 연구개음화된 어두운 $/ 1 /$ 의 경우, 혓몸이 연 구개쪽으로 더욱 들어가야 하고 그 결과 $\mathrm{F} 2$ 는 훨씬 낮은 값을 갖게 된다. 일부 $/ 1 /$ 의 경우 다른 $/ 1 /$ 에 비해 연구개음화가 더욱 심 화되는데 그 이유는 $/ 1 /$ 을 생성할 때 설첨과 설배가 모두 상승하 면서 그러한 혀의 상승 움직임의 정도와 시기가 $/ 1 /$ 의 연구개음 화에 영향을 주기 때문이다. Turton(2014)은 혀의 초음파 촬영을 통한 $/ 1 /$ 의 변이음에 대한 연구에서 $/ 1 /$ 의 연구개음화란 설첨의 움직임이 지연됨과 동시에 약화된 상태로 $/ 1 /$ 을 발음하는 것, 혹 은 지연되거나 약화된 상태로 $/ 1 /$ 을 발음하는 것으로 보았다. 이 는 더 어두운 $/ 1 /$, 즉 연구개음화가 더욱 심화된 $/ 1 /$ 의 경우, 조음 적 측면에서 볼 때 설배가 더욱 뒤로 물러나면서 내려간다는 것 이다. Received Pronunciation(RP)과 같은 영국 영어에서는 밝은 $/ 1 /$ 과 어두운 $/ 1 /$ 의 차이가 변이음을 두 개의 범주로 규정하는 시 각에 힘을 실어주는 반면, 미국 영어에서의 밝은 /1/과 어두운 /1/ 의 차이에는 점진적인 측면이 있다고 보았다. 하지만 이를 통해 /1/의 변이음에 대한 범주적인 접근 방식을 무시하고 연속체의 속성이 있다고 주장할 수 있을 정도는 아니라고 주장하였다.

$/ 1 /$ 의 두 개의 변이음의 차이에 영향을 주는 요소에 대한 연구 에서는 $/ 1 /$ 이 음절내의 어느 위치에서 실현이 되는가에 따라 영 어의 $/ 1 /$ 의 음향 특성이 달라진다는 결과가 있는데, EspyWilson(1992)의 연구에서는 미국 영어의/w j r 1/을 구별할 수 있 도록 하는 언어학적 특징과 연관된 음향학적 자질을 측정한 연 구에서, 이들을 구별하기 위해 포만트 정보를 활용하였다. 영어 의 /1/이 음절 내 모든 위치에서 $2,500 \mathrm{~Hz}$ 이상의 $\mathrm{F} 3$ 값을 가지는 것으로 나타났고, $\mathrm{F} 1$ 의 경우에는 약 $400 \mathrm{~Hz}$ 정도로 음절 말 위 치에서 모음 $/ \mathrm{u} /$ 와 같은 어두운 $/ 1 /$ 이 실현되면 $\mathrm{F} 1$ 이 높아지는 것 을 확인할 수 있었다. 이는 F1이 개구도와 연관이 있다는 점을 고려하면 음절 말 환경에서 모음 / $\mathrm{u} /$ 와 유사한 연구개음화된 / $/ /$ 의 F1 값이 밝은 $/ 1 /$ 의 $\mathrm{F} 1$ 값보다 높게 나타난다는 것은 예측하기 어렵지 않은 일이다. 후설성과 연관된 F2의 경우에는, 혓몸이 뒤로 이동하는 어두운 /1/의 F2 값이 낮게 나타나며, 이 연구에서 는 음절 초와 모음 사이 위치에서는 $1,050 \mathrm{~Hz}$ 이상이지만 음절 말 위치에서는 $600 \mathrm{~Hz}$ 이하의 결과를 보였다. 이처럼 EspyWilson(1992)의 연구에서는 /1/의 변이음을 구별하는 음향학적 자질로 포만트 정보를 사용하고 있으며, 이러한 포만트 값이 유 의미한 차이를 보일 때 서로 연구개음화 정도에 차이를 보이는 변이음으로 구별할 수 있을 것이다.

Recasens \& Farnetani(1990)의 연구에서는 설측음이 연구개음 화되는 정도를 일종의 연속체로 볼 수 있고, 언어마다 이 연속 체 상에서 어떤 음이든 변이음으로 선택하게 되며 개수도 두 개 로 국한된 것은 아니라는 주장을 하였다. Sproat \& Fujimura (1993)는 강약격의 강세가 실현되는 / i - I/ 환경 속에 다양한 종 류의 음운 경계에 인접한 설측음 $/ 1 /$ 을 분석 대상으로 삼았고, 이 러한 음운 경계에 인접한 영어의 /1/의 경우, 그 음이 음절 내에 서 어느 위치에 있는지 그리고 /1/이 포함된 운(rime)의 길이가
어느 정도인지와 같은 요인에 따라 연구개음화가 전혀 일어나 지 않는 표준적인 밝은 $/ 1 /$ 에서부터 연구개음화가 완전히 진행 된 표준적인 어두운 /1/로 이어지는 연속체 상의 음으로 실현된 다고 밝혔다. Yuan \& Liberman(2011)의 연구에서는 /1/의 변이음 에 대해 표준적인 두 개의 변이음이 있다는 주장을 지지하지만, 모음 사이에서 실현되는 /1/의 경우에는 어두운 /1/이나 밝은 /1/ 로 실현되는 것이 모두 가능하고 모음 사이에 오는 설측음이 어 두운 $/ 1 /$ 로 실현되는 경우에 음절 말 환경의 표준적인 어두운 $/ 1 /$ 보다 덜 어둡다고 지적하면서, 표준적인 $/ 1 /$ 에 비해 연구개음화 가 덜 이루어질 수 있다고 주장하였다.

Recasens(2012)는 23개의 언어 및 방언에 대한 연구에서 일부 언어 및 방언의 경우, $/ 1 /$ 의 연구개음화가 중간 정도 진행된 상태 의 변이음이 나타날 수 있다는 점을 밝혔다. Rodrigues et al.(2019)는 유럽 포르투갈어(European Portuguese)의 /1/의 경우 $\mathrm{F} 2$ 가 $1,000 \mathrm{~Hz}$ 정도로 일관되게 낮게 나타나며 이는 음절 내의 모든 위치에서 /1/이 연구개음화되었다는 것을 나타내고 F1과 $\mathrm{F} 3$ 에서의 차이를 통해 음절 내의 위치와 인접 모음과 같은 몇 가지 요소로 인해 연구개음화 정도가 달라질 수 있다는 점을 밝 혔다.

영어의 경우에도 설측음 $/ 1 /$ 에 대한 조음적 측면에서의 연구 와 음향학적 측면에서의 연구 역시 있었으나 대화체 자연발화 에서의 $/ 1 /$ 의 연구개음화가 $/ 1 /$ 의 음절 내 출현 위치와 인접 모음 환경에 따라 얼마나 영향을 받는지에 대한 연구는 드물다. 이 연구의 목적은 미국영어 자연발화 음성 데이터베이스인 벅아 이 코퍼스를 이용하여 미국 영어 설측음의 변이음에 대해 고찰 해 보는 것이다. 벅아이 코퍼스를 연구 대상으로 선택한 이유는 다수의 화자 데이터를 확보하면서 다수 화자의 데이터를 사용 한 다른 연구에 비해 데이터베이스 구축에 걸린 기간이 짧아 동 시대성을 확보할 수 있다는 점 때문이다.

본 연구는 자연발화 데이터베이스인 벅아이 코퍼스를 이용 하여 설측음의 음향학적인 특징을 관찰함으로써 변이음을 유 의미하게 세분화할 수 있다는 가설을 바탕으로 하였다. 음절말 환경에서의 설측음은 전통적으로 연구개음화가 일어난다고 알 려져 있는데 이는 설측음을 조음하는 과정에서 설첨이 치경에 접촉하면서 동시에 설배가 연구개 방향으로 움직이게 되는 2차 조음에 따른 현상이라고 볼 수 있다. 이러한 2차 조음의 특성이 나 정의상 $/ 1 /$ 의 연구개음화는 설배의 움직임이 관여하므로 범 주적이라기보다는 점진적일 것으로 예측할 수 있다. 또한 동일 한 음절 위치에서 선행 모음 혹은 후행 모음이 미치는 영향은 동시 조음에 의한 것으로 이 또한 동시 조음의 특성상 /1/ 연구개 음화의 연속적인 측면을 예상할 수 있는 부분이다. 이를 근거로 영어 설측음의 경우 연구개음화의 정도가 유의미하게 다른 여 러 개의 변이음들로 세분화할 수 있다는 가설을 설정하게 되었 다. 이러한 가설을 확인하기 위해 설측음의 음절 내 출현 위치 에 따라 유의미하게 구별되는 변이음에는 어떤 것이 있는지 알 아보고, 이에 더해 동일한 음절 위치 안에서 후행 모음 또는 선 행 모음의 영향에 의해 표준적인 어두운 /1/과 표준적인 밝은 /1/ 이외에 유의미하게 구별 가능한 $/ 1 /$ 의 변이음에 대해서 살펴보 
고자 한다.

\section{2. 연구 방법}

\section{1. 음성 데이터}

이 연구에서 사용한 음성 데이터는 벅아이 코퍼스로 40 명의 화자의 인터뷰 내용으로 구축된 대화체 음성 코퍼스이다(Pitt et al., 2005), 녹음에 참여한 대상은 모두 중부 오하이오에 거주하 는 사람들로 남성과 여성이 동일한 비율로 각각 20 명씩 참여했 다. 모든 화자는 중산층 백인들로 각자 편하게 인터뷰에 응하여 학교, 스포츠, 정치와 교통과 같은 일상적인 주제에 대해 약 1시 간 동안 대화를 나눈 것이 녹음되었고, 이는 모두 약 300,000 개 의 단어에 달한다. 인터뷰 대상의 발화는 모두 자동으로 전사되 었고 본 연구에서는 벅아이 코퍼스에 [1]과 음절 핵 위치에서의 /1/에 해당하는 [el]로 전사된 설측음에 대해 연구하였다. 인터뷰 진행자의 발화를 비롯하여 화자의 웃음, 잡음, 휴지 구간 등의 비언어적 소리는 개별음으로 전사되지 않았고, 본 연구에서는 $/ 1 /$ 의 음절 내 출현 위치와 인접 모음의 후설성이 $/ 1 /$ 의 연구개음 화 현상에 미치는 영향에 대해 알아보고자 했으므로 이러한 비 언어적 소리 환경은 연구 대상에서 모두 제외하였다. 이 연구에 서 사용된 설측음을 포함하는 토큰의 수는 26,501 개이다.

\section{2. 음향음성학적 특징 측정}

데이터에 대한 음향음성학적 특징 측정에는 Praat 6.0 .38

(Boersma \& Weenink, 2018)과 Phonometrica 0.7.4(Eychenne \& Courdès-Murphy, 2019)를 사용하였다. Phonometrica는 실험에서 확인하고자 하는 각각의 환경속의 $/ 1 /$ 에 대한 음향 데이터를 추 출하는데 이용하였으며, 이 과정에서 음성파일과 함께 벅아이 코퍼스의 레이블 파일을 Praat의 음성전사 파일 형태인 TextGrid 파일로 전환한 파일이 사용되었다(Yoon, 2012).

측정에 사용한 매개변수는 포만트 주파수와 길이로, $/ 1 /$ 의 F1, $\mathrm{F} 2, \mathrm{~F} 3$ 값과 길이 정보가 자동으로 추출되었다. 포만트 주파수 값을 자동으로 추출하는 과정에서 더욱 정확한 결과를 얻기 위 해 lpc order(linear predictive coding order)와 최대 주파수 항목을 Weenink(2015)에 근거하여 설정하였다. 최대 주파수 항목의 경 우, 여성 화자의 데이터에 대해서는 $5,500 \mathrm{~Hz}$, 남성 화자의 데이 터에 대해서는 $5,000 \mathrm{~Hz}$ 로 설정하였고 $\mathrm{lpc}$ order의 경우 11 을 이 용하여 각각의 토큰에 대한 구간의 중간 지점의 포만트 주파수 를 추출하였다. 자동 추출 오류로 인해 생성된 이상치(outliers) 로 여겨지는 일부 포만트 주파수 값을 제외할 필요가 있어서 Rodrigues et al.(2019)의 연구에서 제시된 포만트 주파수 임계값 을 이용하여 오류 데이터를 배제하였으며, 사용한 포만트 주파 수 임계값은 F1의 경우 $200 \mathrm{~Hz}$ 초과, $900 \mathrm{~Hz}$ 미만, $\mathrm{F} 2$ 의 경우 700 $\mathrm{Hz}$ 초과 $2,600 \mathrm{~Hz}$ 미만이고 $\mathrm{F} 3$ 의 경우 $1,600 \mathrm{~Hz}$ 초과 $3,900 \mathrm{~Hz}$ 미 만이다. 오류 데이터를 배제하고 분석에 사용한 토큰의 수는 총 22,149 개이다. 이들 토큰에 대해 자동 추출한 음향 정보에 $/ 1 /$ 의 음절 내 출현 위치와 인접음의 자연 집단 정보를 추가하여 정리 하였다. 그림 1 에서는 인접 모음의 자연 집단 정보가 추가된 각
각의 토큰들에 대해 측정된 음향정보를 후행 모음의 종류에 따 라 정렬한 상태로 일부 제시하고 있다.

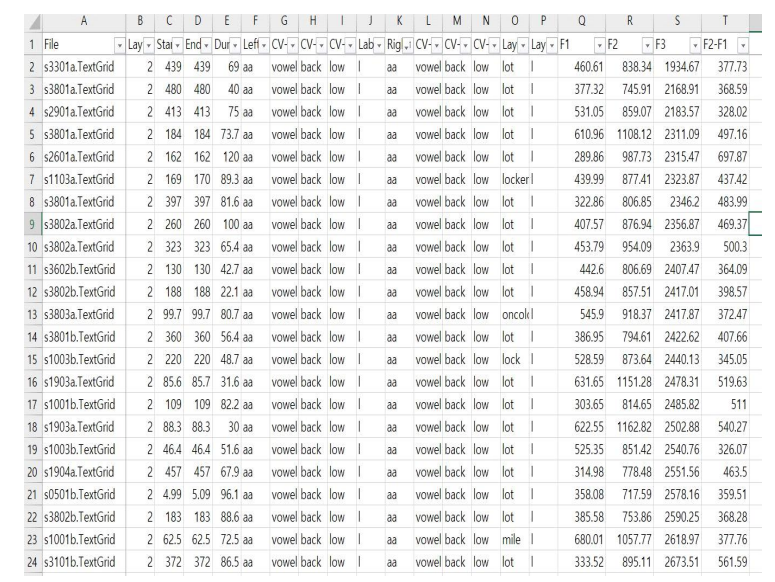

그림 1. /1/에 대한 음향 정보와 인접음의 정보 중 일부

Figure 1. Part of acoustic measurements of /1/ and phonological information on adjacent sounds

\section{3. 연구 결과}

3.1. $/ 1$ 의 음절 내 출현 위치의 영향

자동 추출을 통해 얻은 설측음의 F1, F2, F3 값의 평균과 표준 편차는 표 1 에서 제시한 바와 같다.

Rodrigues et al.(2019)의 유럽 포르투갈어(European Portuguese) 의 /1/의 연구에서는 F2 주파수가 $1,000 \mathrm{~Hz}$ 정도로 일관되게 낮 게 나타나서 음절 내의 모든 위치에서 $/ 1 /$ 의 연구개음화가 어느 정도 이루어지고 있음을 보여주었는데, 표 1 에 제시된 것처럼 벅아이 코퍼스를 중심으로 한 미국 영어 음성데이터의 경우에 는 F2 주파수가 설측음의 음절 내 출현 위치에 따라 차이가 있 음을 확인할 수 있다. 이는 음절 내의 설측음의 출현 위치에 따 른 F1, F3 주파수를 비교했을 때 나타나는 미미한 차이와 비교 했을 때 상대적으로 큰 차이로 인식된다. F2 주파수가 음절 내 출현 위치에 따라 음절 말 위치와 음절 핵 위치에서는 $1,000 \mathrm{~Hz}$ 이하까지 낮게 나타나서 표준적인 연구개음화가 이루어지고 있음을 보여주는데 이러한 F2 주파수가 음절 내 설측음의 출현 위치에 따라 차이가 있으므로 이를 통해 설측음의 연구개음화 가 이루어지는 정도에 차이가 있을 수 있음을 알 수 있다. 이러 한 차이가 유의미한지 확인하기 위해 SPSS 26 을 이용하여 /1/의 포만트 값에 대해 /1/의 음절 내 출현 위치를 요인 변수로 한 일 원배치 분산분석(One-way ANOVA)을 실행하였고 결과는 음절 내의 위치에 따라 $/ 1 /$ 의 포먼트 값이 유의미한 차이를 보이는 것 으로 나타났다[F1 $F(3,22145)=104.755, p<.05 ; \mathrm{F} 2 F(3,22145)=$ $652.128, p<.05 ; \mathrm{F} 3 F(3,22145)=17.067, p<.05]$. Tukey 사후분석 의 결과 $\mathrm{F} 1$ 의 경우에는 음절 말의 $/ 1 /$ 은 다른 모든 위치의 $/ 1 /$ 과 유의미한 차이를 보였지만 다른 위치의 $/ 1 /$ 은 서로 유의미한 차 이를 보이지 않았고, F3의 경우에는 모음 사이의 /1/만이 다른 위 치의 $/ 1 /$ 과 유의미한 차이를 보이는 것으로 나타났다. 한편, 후설 
표 1. 음절 내 출현 위치에 따른 설측음의 포만트 $(\mathrm{Hz})$

Table 1. Descriptive statistics for formant frequencies of lateral liquids in different syllable positions (Hz)

\begin{tabular}{c|c|c|c|c|c|c|c|c|c}
\hline \multirow{2}{*}{ 설측음 위치 } & \multicolumn{3}{|c|}{$\mathrm{F} 1$} & \multicolumn{2}{|c|}{$\mathrm{F} 2$} & \multicolumn{2}{c}{$\mathrm{F}$} \\
\cline { 2 - 11 } & 개수 & 평균 & 표준편차 & 개수 & 평균 & 표준편차 & 개수 & 평균 & 표준편차 \\
\hline 음절 초 & 7,420 & 434.31 & 118.19 & 7,420 & $1,156.59$ & 268.00 & 7,420 & $2,703.45$ & 411.90 \\
\hline 모음사이 & 7,626 & 437.93 & 112.74 & 7,626 & $1,093.58$ & 255.74 & 7,626 & $2,749.25$ & 421.77 \\
\hline 음절 말 & 4,450 & 468.54 & 117.38 & 4,450 & 999.86 & 174.83 & 4,450 & $2,724.95$ & 395.43 \\
\hline 음절 핵 & 2,653 & 429.99 & 95.07 & 2,653 & 959.95 & 191.60 & 2,653 & $2,708.49$ & 400.37 \\
\hline
\end{tabular}

성과 관련되어 연구개음화의 특성을 보여준다고 할 수 있는 F2 의 경우, 음절 내 모든 위치의 $/ 1 /$ 에 대해 서로 유의미하게 차이 가 있는 것으로 나타나서 음절내의 설측음의 출현 위치에 따라 연구개음화되는 정도가 유의미하게 다르다고 할 수 있다. 즉, $/ 1 /$ 이 음절초, 모음 사이, 음절말 위치, 그리고 음절핵으로 실현됨 에 따라 F2 주파수가 유의미한 차이를 보이며 낮아지므로 음절 초에서는 연구개음화되지 않지만 모음 사이 환경, 음절 말 환경, 음절 핵 환경으로 설측음이 출현하는 환경이 바뀌게 되면 점점 연구개음화가 더욱 심화되는 것을 확인할 수 있었다. 한편, 이 처럼 /1/의 음절 내 출현 위치에 따라 포만트 값이 유의미하게 다 른 설측음이 두 개 이상 있다는 실험 결과는 음운론적으로 두 개의 변이음이 존재한다는 주장에 대해 연구개음화 정도에 차 이가 나는 /1/의 변이음들이 그 이상 존재할 수 있다는 주장을 음 성학적으로 뒷받침해주는 것이라고 할 수 있다.

\section{2. 인접 모음의 영향}

설측음의 음절 내 출현 위치에 따라 연구개음화 정도에 유의 미한 차이가 있다는 점을 확인했는데 이때 인접 모음의 특성이 설측음의 연구개음화에 미치는 영향을 살펴보고자 하였다. 먼 저 음절 내 출현 위치에 따라 인접 모음의 위치가 달라지므로 음절 내의 위치에 따라 설측음을 분류한 후, 음절 초의 설측음 에 대해서는 후행 모음의 영향을 알아보고, 음절 말의 설측음에 대해서는 선행 모음의 영향을, 모음 사이의 설측음에 대해서는 선행 모음과 후행 모음의 상호작용이 있는지 알아보았다.

\subsection{1. 음절 초의 설측음에 대한 후행 모음의 영향}

영어의 $1 / /$ 을 생성하는 과정에서 혓몸이 연구개쪽으로 더욱 들어가면서 실현되는 연구개음화된 설측음의 경우, 인접 모음 의 후설성 정도가 설측음의 연구개음화를 심화시킬 것이므로 인접 모음의 후설성에 따른 설측음의 연구개음화에 정도의 차 이가 있는지 확인해보는 것이 필요하다. 먼저 음절 초의 설측음 의 연구개음화 정도가 인접 모음의 후설성에 따라 유의미한 차 이를 보이는지 확인하기 위해 후행 모음의 후설성에 따른 /1/의 포만트 주파수를 표 2에서 정리하였다.

설측음의 후행 모음이 전설모음인 경우, 설측음의 F2 주파수. 값이 $1,214 \mathrm{~Hz}$ 로 후행 모음이 중설모음이나 후설모음인 경우와 비교했을 때 상당히 높게 나타났다. 음절 초 위치의 설측음의 경우에는 후행 모음이 전설모음일 때에는 연구개음화되지 않 지만 후행 모음이 후설모음이거나 중설 모음일 때 F2 주파수값 이 각각 $1,005 \mathrm{~Hz}, 1,030 \mathrm{~Hz}$ 로 낮게 나타나 후설의 움직임이 커
지며 연구개음화된 것으로 보인다. 그림 2는 후행 모음에 따른 이들 설측음의 F2 주파수 값의 분포를 나타낸 것이다.

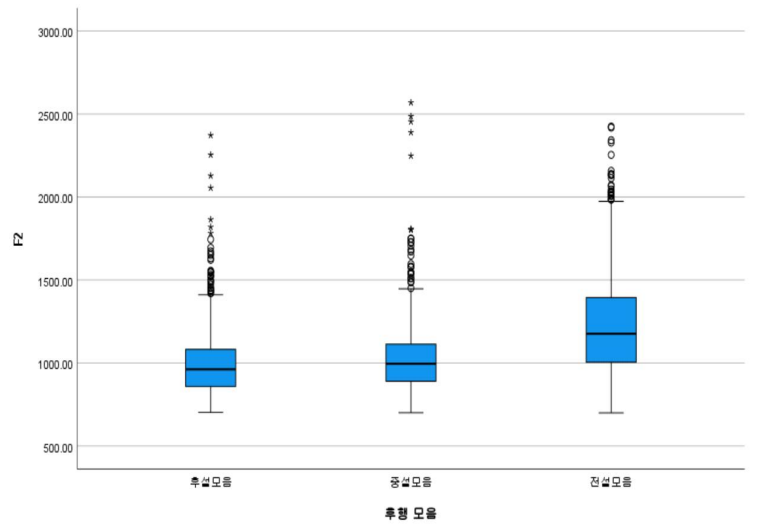

그림 2. 후행 모음에 따른 음절 말 위치의 /1/의 F2(Hz)

Figure 2. F2 frequencies of prevocalic lateral liquids classified by backness of following vowels $(\mathrm{Hz})$

이러한 차이가 유의미한 것인지 확인하기 위해 일원배치 분 산분석(one-way ANOVA)을 통해 알아본 결과는 후행 모음의 후 설성에 따른 /1/의 포만트 주파수는 유의미하게 다른 것으로 나 타났다 $[\mathrm{F} 1 F(2,4320)=8.065, p<.05 ; \mathrm{F} 2 F(2,4320)=246.450, p<.05$; $\mathrm{F} 3 F(2,4320)=4.283, p<.05]$. Tukey 사후분석의 결과, 이들 중 전 설모음과 후설모음의 경우에만 포만트 주파수가 유의미하게 다른 것으로 나타났다.

\subsection{2. 음절 말의 설측음에 대한 선행 모음의 영향}

음절 말 환경의 설측음에 대해서도 인접 모음의 후설성이 설 측음의 연구개음화에 유의미한 차이를 보이는지 확인하기 위 해 선행 모음의 후설성에 따른 $/ 1 /$ 의 포만트 주파수를 표 3 에서 정리하였다.

이에 대한 일원배치 분산분석 결과 $\mathrm{F} 3$ 의 경우에는 그 차이가 전혀 유의미하지 않았다[F3 $F(2,4356)=1.098, p>.05]$. 하지만, $\mathrm{F} 1$ 과 $\mathrm{F} 2$ 측면에서는 유의미한 차이를 보였다[F1 $F(2,4356)=$ $21.383, p<.05 ; \mathrm{F} 2 F(2,4356)=106.745, p<.05]$. Tukey 사후분석의 결과는, 이들 중 선행 모음이 전설 모음일 경우에 한해 선행 모 음이 중설 모음이거나 후설 모음일 경우와 포만트 주파수가 유 의미하게 다르게 나타났다. 선행 모음에 따른 이들 설측음의 F2 주파수 값의 분포는 그림 3에서 보여주고 있다. 
표 2. 후행 모음에 따른 음절 초 위치의 $/ 1$ 의 포만트 $(\mathrm{Hz})$

Table 2. Descriptive statistics for formant frequencies of prevocalic lateral liquids classified by backness of following vowels (Hz)

\begin{tabular}{c|c|c|c|c|c|c|r|r|c}
\hline \multirow{2}{*}{ 후행 모음 } & \multicolumn{3}{|c|}{$\mathrm{F} 1$} & \multicolumn{2}{|c|}{$\mathrm{F} 2$} & \multicolumn{3}{c}{$\mathrm{F} 3$} \\
\cline { 2 - 10 } & 개수 & 평균 & 표준편차 & 개수 & 평균 & 표준편차 & 개수 & 평균 & 표준편차 \\
\hline 후설모음 & 625 & 397.74 & 111.72 & 625 & $1,005.29$ & 221.78 & 625 & $2,692.60$ & 381.94 \\
\hline 중설모음 & 647 & 403.01 & 114.51 & 647 & $1,030.20$ & 227.58 & 647 & $2,675.46$ & 435.45 \\
\hline 전설모음 & 3,051 & 415.12 & 111.68 & 3,051 & $1,214.56$ & 281.49 & 3,051 & $2,723.11$ & 417.08 \\
\hline
\end{tabular}

표 3. 선행 모음에 따른 음절 말 위치의 /1/의 포만트 $(\mathrm{Hz})$

Table 3. Descriptive statistics for formant frequencies of postvocalic lateral liquids classified by backness of preceding vowels (Hz)

\begin{tabular}{c|c|c|c|c|c|c|c|c|c|c|}
\hline \multirow{2}{*}{ 선행 모음 } & \multicolumn{3}{|c|}{$\mathrm{F} 1$} & \multicolumn{3}{|c|}{$\mathrm{F} 2$} & \multicolumn{2}{c}{$\mathrm{F} 3$} \\
\cline { 2 - 11 } & 개수 & 평균 & 표준편차 & 개수 & 평균 & 표준편차 & 개수 & 평균 & 표준편차 \\
\hline 후설모음 & 1,750 & 456.82 & 119.50 & 1,750 & 956.29 & 165.73 & 1,750 & $2,733.21$ & 392.33 \\
\hline 중설모음 & 754 & 456.14 & 114.81 & 754 & 993.69 & 172.26 & 754 & $2,707.66$ & 384.21 \\
\hline 전설모음 & 1,855 & 479.85 & 113.07 & 1,855 & $1,039.13$ & 173.90 & 1,855 & $2,725.24$ & 403.77 \\
\hline
\end{tabular}

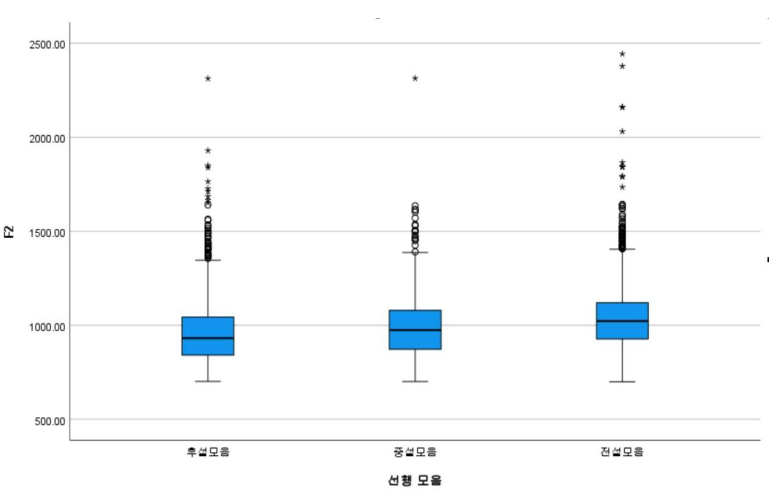

그림 3. 선행 모음에 따른 음절 말 위치의 /1/의 F2(Hz)

Figure 3. F2 frequencies of postvocalic lateral liquids classified by backness of preceding vowels $(\mathrm{Hz})$

음절 말에 위치한 설측음의 경우 선행 모음의 종류와 무관하 게 F2가 $1,000 \mathrm{~Hz}$ 내외로 매우 낮게 나타나서 전반적으로 연구 개음화 되었음을 확인할 수 있지만 선행 모음이 중설 모음이거 나 후설 모음일 경우 선행 모음이 전설 모음일 경우보다 F2 주 파수가 유의미하게 낮게 나타나 설배가 더욱 뒤로 물러나 있음 을 알 수 있고, Espy-Wilson(1992)에 따라 이러한 조음적인 움직 임이 연구개음화를 점진적으로 심화시키는 것으로 판단된다.

\subsection{3. 모음 사이 환경의 설측음에 대한 모음의 영향}

모음 사이 환경의 설측음의 경우 음절재구성이 일어나는 시 점에 따라 연구개음화의 정도가 달라질 것으로 예상된다. 설측 음의 선행모음과 후행모음의 후설성이 / $1 /$ 의 연구개음화에 미치 는 영향을 확인하기 위해 일원배치 분산분석(one-way ANOVA) 을 시행한 결과 모두 유의미하게 다른 것으로 나타났다.

하지만 이원배치 분산분석을 통해 선행모음과 후행모음의 상호작용 효과를 검증한 결과 부분 에타 제곱(부분 $\left.\eta^{2}\right)$ 이 0.005 로 상호작용 효과는 기대할 수 없었다.

설측음의 인접 음이 양쪽 모두 모음인 경우, 연구개음화 여부 를 각 환경에 따른 $/ 1 /$ 의 F2 주파수를 표 4 에서 정리하였다.
표 4. 인접 모음의 종류에 따른 모음 사이의 /1/의 F2(Hz) Table 4. Descriptive statistics for formant frequencies of intervocalic lateral liquids classified by backness of adjacent vowels $(\mathrm{Hz})$

\begin{tabular}{c|r|r|r}
\hline \multirow{2}{*}{ 후행 모음 } & \multicolumn{3}{|c}{ 선행 모음 } \\
\cline { 2 - 4 } & 후설모음 & 중설모음 & 전설모음 \\
\hline 후설모음 & $1,031.25$ & 943.87 & $1,095.72$ \\
\hline 중설모음 & 989.10 & $1,020.82$ & $1,080.21$ \\
\hline 전설모음 & $1,086.01$ & $1,089.81$ & $1,198.06$ \\
\hline
\end{tabular}

표 4를 통해 확인할 수 있듯 예상했던 것처럼 설측음의 선, 후 행 모음이 모두 전설 모음인 경우 F2 주파수가 가장 높게 나타 나 /1/의 연구개음화를 방해하는 요소로 생각할 수 있을 것으로 보이나 선행 모음과 후행 모음이 모두 후설모음일 경우보다 선 행 모음이 중설 모음이고 후행 모음이 후설 모음이거나 선행 모 음이 후설 모음이고 후행 모음이 중설 모음인 경우에 오히려 F2 주파수가 더 낮게 나타난 점으로 미루어 모음 사이 위치에 출현 한 설측음의 F2 주파수가 낮게 실현되도록 하는 요인에는 인접 모음의 후설성 이외의 다른 요인이 있음을 예측하게 한다. Turton(2014)의 혀의 초음파 촬영을 통한 설측음의 변이음에 대 한 연구 결과 설첨의 움직임이 지연되는 것과 약화되는 것을 연 구개음화를 심화시키는 움직임으로 판단했던 점을 유념할 때 모음 사이의 설측음의 경우 설첨의 움직임의 약화와 관련 있는 인접 모음의 강세 역시 연구개음화에 복합적인 영향을 미치는 요인으로 판단된다. 이에 인접 모음의 강세 환경을 고려하여 설 측음의 연구개음화 정도를 비교하는 후속 연구가 의미 있을 것 으로 보인다.

\section{4. 결론}

본 연구에서는 영어 설측음/1/이 음절 말 환경 이외에서도 연 구개음화가 진행되어 표준적인 어두운 [1]과 표준적인 밝은 [1] 사이에 연구개음화의 실현 정도가 유의미하게 다른 변이음이 있는지 확인하기 위해 벅아이 코퍼스를 이용하였다. 설측음의 음절 내 출현 위치에 따라 네 종류로 구분하여 포만트 주파수를 비교한 결과 F2 주파수의 차이가 음절 내 출현 위치에 따라 유 
의미하게 다르게 나타나서 음절 내 설측음의 출현 위치에 따른 연구개음화의 정도에 차이가 있다는 것을 확인할 수 있었다. 이 때, 혀의 후설성과 연관 있는 F2 주파수가 설측음이 음절 내 출 현하는 모든 위치에 대해 유의미한 차이를 보이는 것으로 보아 연구개음화 정도가 유의미하게 다른 변이음이 여러 개 존재할 수 있다고 판단할 수 있다. 이들은 F1, F3 주파수에서도 차이를 보여 주장을 좀 더 뒷받침하고 있다. 음절핵으로 전사된 설측음 의 경우, 이미 모음과 유사한 특성을 가지고 있다고 판단하여 제외하더라도 연구개음화가 어두운 [1]과 밝은 [1]의 중간 정도 수준으로 진행된 또 다른 변이음이 존재한다고 볼 수 있다.

인접 모음의 특성이 설측음의 연구개음화에 미치는 영향으 로 인해 어두운 [1]과 밝은 [1]의 중간 정도 수준으로 연구개음화 가 진행된 또 다른 변이음이 존재하는지 알아보기 위해 음절 내 의 각 위치에서 인접 모음 종류에 따른 /1/의 포만트 주파수를 측 정하였다. 그 결과, 음절 말 위치의 $/ 1 /$ 의 경우에는 $\mathrm{F} 2$ 주파수가 $1,000 \mathrm{~Hz}$ 정도로 낮게 나타나 전체적으로 어두운 [1]로 발화되었 다고 볼 수 있으나 그 중 유의미하게 낮은 F2 주파수를 보인 경 우가 선행 모음이 후설 모음 혹은 중설 모음인 경우로 이는 설 측음의 변이음인 어두운 [1] 중에서도 연구개음화의 정도에 유 의미한 차이가 있는 더욱 어두운 [1]이 존재한다는 것을 보여준 다고 할 수 있다. 뿐만 아니라 음절 초 위치에서 F2 주파수가 $1,214 \mathrm{~Hz}$ 로 나타나는 전설 모음 앞의 설측음과 달리 후설 모음 앞의 설측음의 경우 음절 말 위치의 설측음의 경우보다 F2 주파 수가 낮게 나타나 연구개음화가 진행되고 있음을 확인할 수 있 다. 이러한 결과는 음절 내의 설측음의 출현 위치보다 인접 모 음의 후설성의 영향이 크다는 점을 시사한다고 할 수 있다.

\section{감사의 글}

본 연구를 위해 phonometrica를 활용하는데 도움을 주신 Julien Eychenne 교수님께 감사드립니다.

\section{References}

Boersma, P., \& Weenink, D. (2018). Praat: Doing phonetics by computer (version 6.0.38) [Computer program]. Retrieved from http://www.praat.org/

Chomsky, N., \& Halle, M. (1968). The sound pattern of English. New York, NY: Harper \& Row.

Espy Wilson, C. Y. (1992). Acoustic measures for linguistic features distinguishing the semivowels /w j r 1/ in American English. The Journal of the Acoustical Society of America, 92(2), 736-757.

Eychenne, J., \& Courdès-Murphy, L. (2019, November). Phonometrica: An open platform for the analysis of speech corpora. Proceedings of the Seoul International Conference on Speech Sciences 2019 (pp. 107-108). Retrieved from http://www.phono metrica-ling.org/. Seoul, Korea.
Jones, D. (1966). The pronunciation of English. Cambridge, UK: Cambridge University Press.

Ladefoged, P., \& Johnson, K. (2014). A course in phonetics. Stamford, CT: Cengage Learning.

Pitt, M., Johnson, K., Hume, E., Kiesling, S., \& Raymond, W. (2005). The Buckeye corpus of conversational speech: Labeling conventions and a test of transcriber reliability. Speech Communication, 45(1), 89-95.

Pitt, M. A., Dilley, L., Johnson, K., Kiesling, S., Raymond, W., Hume, E., \& Fosler-Lussier, E. (2007). Buckeye corpus of conversational speech. Retrieved from http://www.buckeye corpus.osu.edu

Recasens, D. (2012). A cross-language acoustic study of initial and final allophones of /1/. Speech Communication, 54(3), 368-383.

Recasens, D., \& Farnetani, E. (1990, November). Articulatory and acoustic properties of different allophones of $/ 1 /$ in American English, Catalan, and Italian. Proceedings of the International Conference on Spoken Language Processing (ICSLP-1990) (pp. 961-964). Kobe, Japan.

Rodrigues, S., Martins, F., Silva, S., \& Jesus, L. M. T. (2019). /1/ velarisation as a continuum. PLOS ONE, 14(3), e0213392.

Sproat, R., \& Fujimura, O. (1993). Allophonic variation in English /1/ and its implications for phonetic implementation. Journal of Phonetics, 21(3), 291-311.

Turton, D. (2014). Some $/ 1 / \mathrm{s}$ are darker than others: Accounting for variation in English /1/ with ultrasound tongue imaging. University of Pennsylvania Working Papers in Linguistics, 20(2), 189-198.

Weenink, D. (2015, August). Improved formant frequency measurements of short segments. Proceedings of the 18th International Congress of Phonetic Sciences. Glasgow, UK.

Yoon, K. C. (2012). Error correction and Praat script tools for the Buckeye corpus of conversational speech. Phonetics and Speech Sciences, 4(1), 29-47.

Yuan, J., \& Liberman, M. (2011). /1/ variation in American English: a corpus approach. Journal of Speech Sciences, 1(2), 35-46.

\author{
- 사재진 (Jae-Jin Sa) 교신저자 \\ 가톨릭관동대학교 VERUM교양대학 조교수 \\ 강원도 강릉시 범일로 579 번길 24 \\ Tel: 033-649-7212 \\ Email: bz2u@cku.ac.kr \\ 관심분야: 음성학, 음운론, 영어교육
}




\title{
벅아이 코퍼스를 이용한 미국 영어의 /1/ 연구개음화 연구
}

\author{
사 재 진
}

가톨릭관동대학교 VERUM교양대학

\begin{abstract}
국문초록
설측음의 변이음에는 어두운 [1]과 밝은 [1]이 있다고 알려져 왔으나 최근 설측음의 변이음의 종류가 언어마다 다르 다는 주장이 제기되고 있다. 본 연구에서는 영어 설측음 $/ 1 /$ 이 음절 내 출현 위치에 따라 연구개음화의 실현 정도가 유의미하게 다른 변이음이 있는지 확인하기 위해 자연발화 음성 데이터베이스인 벅아이 코퍼스를 이용하였다. 먼 저, 설측음의 음절 내 출현 위치에 따라 측정한 포만트 주파수를 비교한 결과 음절 내 모든 위치에서 유의미한 차이 를 보이는 F2 주파수를 근거로 연구개음화 정도가 유의미하게 다른 변이음이 어두운 [1]과 밝은 [1] 이외에도 존재 한다고 판단할 수 있었다. 또한 인접 모음의 후설성이 설측음의 연구개음화에 미치는 영향으로 인해 표준적인 어 두운 [1]과 표준적인 밝은 [1] 이외의 변이음이 존재하는지 확인하기 위해 포만트 주파수를 측정하고 이에 대해 분산 분석을 한 결과 음절 말 위치에서 연구개음화될 때에도 인접 모음이 후설모음인 경우 인접 모음이 전설모음인 경 우와 비교했을 때 유의미하게 차이나는 F2 주파수를 보여 연구개음화되는 정도에 차이가 있음을 확인할 수 있었 다. 이는 음절 초 위치에서 설측음이 실현될 경우에도 마찬가지로 인접 모음의 종류에 무관하게 모든 설측음이 음 절 초 위치에서는 표준적인 밝은 [1]로 발음될 것이라고 예측했지만 실제 F2 주파수는 음절 말 위치에서 선행모음 이 전설모음일 경우의 설측음과 유사한 결과를 나타냈다. 이를 통해 음절 내의 위치뿐만 아니라 인접 모음의 후설 성이 설측음의 연구개음화 정도에 미치는 영향이 매우 크다는 점을 확인할 수 있고, 이러한 논문의 결과는 설측음 의 변이음의 종류가 언어마다 다르고 미국 영어의 경우 다양하게 나타난다는 주장에 대한 하나의 음성학적 근거로 사용될 수 있을 것이다.
\end{abstract}

핵심어: 벅아이 코퍼스, 설측 유음, 포만트 주파수, 길이, 인접 모음, 연구개음

\section{참고문헌}

윤규철 (2012). 벅아이 코퍼스 오류 수정과 코퍼스 활용을 위한 프

랏 스크립트 툴. 말소리와 음성과학, 4(1), 29-47. 